\title{
Witchcraft, healing and vernacular magic in Italy
}

\author{
Sabina Magliocco
}

Field notes, 29 October 2001: Bessude, Sardinia. I am walking in the countryside outside this highland pastoral town of 500 inhabitants with Mario, a shepherd in his mid-forties, and his cousin Pina, whom I have known for approximately fifteen years. Mario is telling us how his grandfather taught him and his cousins, Tonino and Basiliu, to charm warts when they were working for him as terrakos (tenant-shepherds) in the 1970s. 'I didn't know you could cure warts too; I thought it was just giaio (grandpa) and Uncle Basiliu,' exclaims Pina. 'He taught all of us this meikina (medicine) before he died. He couldn't die until he had passed it on,' Mario explains. 'Does the cure consist of berbos ('words', a spell) or are there also actions and herbs that you use?' I want to know. 'Only words,' says Mario. 'But does it work?' asks Pina. 'It depends; sometimes,' he replies. He tells us how he recently cured a friend who called him on the phone from Rome to ask for a healing; but he also showed us warts on his own hands that he has not been able to charm away. When I ask him what the words are, he says he believes the cure must remain secret, because passing it on means passing on the power to heal. 'There were lots of people in the village who knew berbos for things: to make birds leave a newly-sown field, or to make dogs go away,' he explains. 'How about keeping eagles away from the lambs?' I ask, thinking of spells I have read in folklorists' collections. 'For that you need a gun,' he says, deadpan.

While the last formal accusations of witchcraft in Italy took place around 1750 , and by the early nineteenth century Enlightenment discourses had relegated supernatural beliefs to 'superstition' among the educated elite and the clergy, vernacular religion and folk belief were far from dead in Italy. Legend complexes about witches and related beings flourished well into the twentieth century, and folk healers continue to practise their craft in both urban and rural areas. In this chapter, I will give a general overview of vernacular magical beliefs and practices in Italy from the time of unification to the present, with particular attention to how these traditions have been 
studied. It is my contention that while many ethnologists have made these practices the focal point of their studies, certain crucial aspects have been ignored or silenced due to the biases of the researchers. I would like to argue for a more experience-centred approach to the study of Italian vernacular religion and belief - one rooted in careful attention to practice, embodied experience and the role of these aspects in daily life, in addition to factors of historicity and power. Only by examining the role of these practices in their entire context can we come to a fuller understanding of what they mean to their practitioners.

Witch beliefs, folk healing and the legend complexes related to them have generally been studied as aspects of 'folk', 'unofficial' or 'popular' belief or religion. But as Leonard Primiano notes, these terminologies presuppose the existence of a hierarchical, dualistic system in which 'official' religion or belief, sanctioned and adopted by the hegemony, has primacy over 'folk', 'popular' and 'unofficial' systems, which are then viewed as inferior or illegitimate. ${ }^{1}$ According to Primiano, the assumption that such practices exist separate from hegemonic practices is inaccurate, since the continuum between official and unofficial religion and belief is fluid and varies according to context. Further, he asserts that this terminology has led to a devaluation of 'folk' belief and a denigration of popular practices. ${ }^{2}$ He proposes instead the use of the term 'vernacular' to describe the dynamic process of lived religion and belief. ${ }^{3}$ In this chapter, I am adopting Primiano's use of the term 'vernacular' and broadening its application beyond the study of religion to include magic. By 'vernacular religion', therefore, I mean the entire range of lived religion, with its complement of material, verbal and behavioural manifestations. By coining the term 'vernacular magic' after Primiano's 'vernacular religion', I am rejecting the dualistic system of 'high magic' versus 'low magic', on the grounds that these, too, constitute an artificial separation of complex, dynamic practices that cut across lines of class and power within a single society. ${ }^{4}$ Of course, power relationships do profoundly influence belief and practice; my adoption of the term 'vernacular' is not meant to deny this, but rather to call attention to how particular individuals shape their own beliefs and practices in response to their social position, as well as to the many ways that vernacular religion and magic can both contest and reinforce power relations in a society.

It is problematic to speak about an 'Italian' vernacular religion or magic before 1861. Italy achieved statehood in 1861 after a thirteen-year struggle known as the Risorgimento. Previously, it was made up of a patchwork of Papal States, principalities and kingdoms without a common language or government. The area we now recognize as Italy spanned areas vastly different in culture, dialect and belief. Nevertheless, there was a certain commonality in vernacular magic and religion that also extended to other areas in Europe. It is perhaps more useful to look at the development of broad 
culture areas within which one can find a certain range of traits: northern Italy, comprising the regions along the Alps and the coastal Venezia-Giulia; central Italy, consisting of areas in Emilia-Romagna, Tuscany, and the northern sections of Umbria and Lazio; and southern Italy, from Civitavecchia (just north of Rome) down to the tip of the boot, including the islands of Sicily and Sardinia. Of course, within these divisions, there exist even finer boundaries, so that each individual region, city, town and small village has its own unique dialect and culture. Italy is part of a broader geographic and cultural region encompassing the western Mediterranean; within this area, regional cultures form distinct clusters. Thus Italy is by no means homogenous, and any generalizations about an 'Italian' vernacular culture need to be treated with great caution.

After Italian unification in 1861, the cultures and traditions of rural peasants in the twenty regions of the new nation-state became the focus of an emergent field of study, variously called storia delle tradizioni popolari (the history of popular traditions), etnologia (ethnology), demologia (the study of the common people), or antropologia culturale (cultural anthropology). Over the course of the late nineteenth and twentieth centuries, these studies drew predominantly from two interpretive strains: survivalist theories and Gramscian materialism. I will argue that while there is much to be said for the deep historicity of many Italian folk practices, and their rootedness in systems of social and economic oppression, these scholarly approaches, embedded as they are in Enlightenment discourses of progressivism, ultimately failed to address the spiritual meaning of the practices. I will argue instead for an experiencecentred approach to folk practice that allows us to view it as an integral part of the individual experience of the numinous. Of course, any attempt to convey an overview of not only vernacular practices, but also the ways in which they have been studied, is bound to be limited in scope, especially in a brief article. Italian folklore scholarship spans over one hundred years and twenty separate regions; this overview cannot pretend to be comprehensive. However, for English readers interested in Italian folk magic and popular religion, I hope I can provide a point of departure from which to evaluate existing sources and discover new ones.

\section{The study of Italian vernacular religion and magic}

Most of the data on which my chapter is based were collected by Italian ethnologists and folklorists between 1880 and 1980, with interruptions during the First and Second World Wars. The study of folklore is never a politically neutral act, however. The kinds of materials collected, and the ways they were presented, were conditioned by the preconceived notions of the scholars collecting them. Italian unification in 1861 was followed by a great wave of urbanization, especially among the elite and middle classes, 
who sought in the life of the cities and the new capital a level of cosmopolitanism and sophistication unavailable in rural areas. This movement led to a surge of Italian nationalism, and a new focus, partly born of nostalgia, on what came to be called tradizioni popolari, popular or folk traditions. Italians located the source of their national identity and cultural authenticity in the Classical period, the last time the peninsula had existed as a unified entity under the aegis of the Roman Empire. Early Italian scholars sought in folklore some kind of link to that Classical past, as well as to that other touchstone of Italian national identity, the Renaissance, in order to show that contemporary Italian culture carried on an ancient, uninterrupted tradition that legitimized the existence of the state.

The early collectors worked from an evolutionary premise. They assumed that the practices of the Italian peasant class were remnants of an ancient, 'primitive' belief system dating back to pre-Classical times, which was destined to disappear as its bearers became 'civilized'. Their attitudes ranged from the affectionate respect that Sicilian collector Giuseppe Pitrè brought to his informants, most of whom were also his medical patients, to the disdain of Giuseppe Bellucci, the title of whose 1919 work Il feticismo primitivo in Italia e le sue forme di adattamento (Primitive Fetishism and its Adaptations in Italy) speaks for itself. ${ }^{5}$ While the work of early collectors has left us a wealth of material, including proverbs, charms, spells, cures and narratives, these scholars made few attempts to understand the role of magical belief systems and practices in the context of the lives of rural agricultural workers. Instead, they often preferred to compare them with the customs of ancient civilizations, so they could 'prove' an uninterrupted oral transmission of culture from Classical times to the founding of the Italian state. Beliefs and practices were presented as fragmentary and incomplete, not as parts of the integrated belief systems of individuals and small communities. They were also stigmatized as the ignorant productions of a peasant underclass. Because most early collectors were men, their concerns reflect those of their male informants. So, for example, we have a great many reports from men about women's power to bind with potent love spells, but we do not know whether this reflects women's actual behaviour, or men's fears and anxieties. More significant still is the absence of ethnographic attention to women's ecstatic traditions connected to saints' cults. It was not until the 1970 s that women began to enter the ethnological professions in greater numbers, and conduct fieldwork centred around women's issues, that more information on women's actual practices became available.

Survivalist perspectives flourished well into the Fascist period in Italy (1922-44), supported by a government whose political interests were served by the projection of contemporary cultural praxes into a gloriously imagined past. But, ultimately, survivalist perspectives were themselves rejected as outdated after the Second World War, as scholarship began to reflect a 
greater interest in contemporary social conditions and issues of power imbalances between the industrialized north and the underdeveloped Meridione (south) in the developing nation-state. It was the Socialist writer Antonio Gramsci, who was imprisoned by Mussolini, who most strongly influenced the post-Second World War generation of Italian ethnologists. Gramsci's writings on folklore were brief, but significant, for they moved Italian ethnology away from survivalism at last. For him, folklore was not a 'survival' that was quickly disappearing, but an integral part of the cultures of rural Italian peasants, and a product of particular historical and cultural circumstances, and worthy of study in its own right alongside literature and history. In genres such as festivals and celebrations, he saw emergent forms of peasant resistance - clever, creative ways the rural underclass subtly undermined the power that the hegemony exercised over their daily lives. Following Karl Marx, Gramsci saw folklore as part of the 'superstructure' of society - those forms and accretions that grow out of particular economic configurations. He also believed that folklore, especially certain forms of folk belief and magical practice, were a kind of 'false consciousness' that ultimately blinded peasants to the forces that oppressed them by hiding the real sources of domination under a veil of mysticism. So while Gramsci idealized folklore as peasant resistance, and sought to legitimize its study as a form of culture in its own right, he also saw popular religiosity and magical practice as ultimately crippling, a relic of the past that needed to be discarded to bring about a more equal distribution of power in society.

This philosophy was very much at the heart of the work of two great Italian folklore scholars of the mid-twentieth century: Alberto Maria Cirese and Ernesto De Martino. Cirese expanded upon Gramsci's theories of folklore, urging its study as part of subaltern culture that existed in contraposition to the hegemony of church and state. De Martino was interested in documenting and analysing Italian magical practice to understand thoroughly how magic worked within the economic, cultural and historical context in which it existed. Thus his groundbreaking studies of the evil eye belief complex and tarantismo emphasize peasants' captivity in a system of social relations rooted in economic, social and gender oppression. Still, despite De Martino's own origins in Naples, centre extraordinaire of the occult in southern Italy, and his deep knowledge of ethnology, he and his followers, like Cirese, saw magic as primarily a tool of the poor and weak, a form of resistance against systematic forms of domination that was ultimately unsuccessful. They assumed that as economic opportunities became available to the subaltern class, folk magical practices would cease to exist.

Both the survivalist perspective and the Marxian attention to materialist context made important contributions to the understanding of folk magical practices by emphasizing their historical continuity with earlier systems of thought, and their relationship to systems of power and domination. However, 
both approaches ultimately failed to address the deeply spiritual nature these practices had for their practitioners. This spiritual significance is, I suspect, the reason why despite the disappearance of Italy's grinding poverty and backwardness by the mid-twentieth century, vernacular magical practice has persisted, albeit in mutated forms. Nor are its manifestations limited to underdeveloped rural areas. As ethnologist Cecilia Gatto Trocchi has shown, urban centres are now the sites of a variety of occult and esoteric practices, from traditional fortune-telling to New Age religious movements, which are rooted in earlier systems of magic and healing. ${ }^{6}$ Today, a new generation of seekers is reviving old practices such as tarantismo as a way of affirming local and regional identities in an increasingly globalized Europe. ${ }^{7}$

\section{The context of Italian vernacular magic}

Italian vernacular magic is rooted in a world-view that developed in smallscale communities where life was difficult and precarious. Until after the Second World War, the majority of the Italian population were contadini (peasants) who resided mostly in small, agricultural towns and villages. Rural conditions varied widely depending on the region, but for most contadini, living conditions were harsh. Many lived under feudal conditions as virtual serfs to powerful landowners. Life in small-scale communities involved intense social relations which often became strained, leading to quarrels, feuds and mutual suspicions between neighbours. Witch belief and accusations of witchcraft must be understood as part of this political and social climate. As Davies and Favret-Saada have demonstrated, such accusations flourish in communities where inhabitants live in close proximity with one another and have histories of conflicts and disagreements. ${ }^{8}$

Another factor contributing to witch beliefs and accusations was lack of access to basic health care and sanitation. Malaria, tuberculosis and typhoid fever were endemic in much of rural Italy before the First World War; in addition, many suffered from congenital blood disorders such as thalassemia and favism. Medical doctors were rare and expensive until 1866, when government-funded physicians were stationed in every small town and hamlet. Still, ordinary people relied on folk healers to cure their ailments and on local midwives to deliver their babies. These women often had extensive knowledge of herbs and their uses, and were able to alleviate a number of minor illnesses, although they could do nothing against life-threatening diseases. There was a sense that life was a precarious enterprise, full of dangers at every turn; magic was one of many protective strategies people employed to ensure their survival and that of their family members. Against this background, most people maintained a magical view of the world.

Vernacular religion played an important part in people's attempts to ameliorate their situations. Before Italian unification, the Catholic Church 
was the most important institution common to all Italians. Catholicism penetrated deeply into the fabric of everyday life, dividing both the year cycle and the life cycle into a series of rites and celebrations that accompanied the individual from cradle to grave. Invocations to the saints, prayers and the use of holy water and sacred objects were an important part of magical practice. Popular saints' cults and celebrations often had at their core both a promessa, or promise of devotion in exchange for good health, and an ecstatic component that could involve dancing, drumming, and extraordinary efforts on behalf of the saint that resulted in participants achieving alternate states of consciousness. These states played an important role in individual spirituality - one that has sometimes been overlooked by researchers. In my fieldwork, I observed that some individuals were deeply and spiritually attracted to religiosity. These people often became involved in religious fraternities and sororities which maintained various calendar customs and saints' shrines, while at the same time running a lively practice in folk healing on the side. Both aspects of their practice could involve ecstatic states. They did not see their practices as incompatible, since they were part of a logical continuum of vernacular religiosity. Priests, as representatives of the power hierarchy within the Catholic Church, often frowned upon (and continue to disparage) such activities; but this never seemed to trouble the spiritual individuals I interviewed. Italians have always harboured a rather healthy anti-clericalism and distrust of institutions and their representatives, and they were able to insert the priest's disapproval into this larger framework of understanding and view it with irony and scepticism.

\section{The folkloric witch}

Belief in witchcraft - that is, that certain individuals, both male and female, had supernatural powers to heal or harm - was once widespread in all regions of Italy. The witch has always been an ambiguous figure in the popular imagination. On one hand, the witch was essential as a healer and unbewitcher in a society that had little access to, and much distrust of, formal medicine. Yet witches were also feared for their supernatural powers and their reputed ability to do harm. Witches were therefore both real individuals living in communities and frightening supernatural figures, and these categories overlapped considerably in people's minds, sometimes giving rise to specific accusations of witchcraft. It is clear that many activities attributed to witches were folkloric in nature - that is, no living member of any community, even traditional magic-workers, practised them. Following Davies's recent work on witch belief in Britain I call these the province of the 'folkloric witch' the supernatural figure of legends and folktales. ${ }^{9}$ The word strega (plural streghe), from the Latin strix, 'screech-owl', is often used in Italian to refer to the folkloric witch, and the word has ancient negative connotations. Pliny 
the Elder wrote about striges (plural of strix), women who could transform into birds of prey by means of magic, and who would fly at night looking for infants in their cradles to slaughter. ${ }^{10}$

The folkloric witch appears predominantly in legends (accounts about supernatural events that were told as true) and folk tales (purely fictional accounts set in a magical world). In Italian folklore she is usually female. Folkloric witches perform feats that are obviously supernatural: they transform into animals; fly through the night sky on the backs of goats; tangle people's hair in their sleep; steal milk from nursing mothers and livestock; suck blood from living beings; and torment their enemies by paralysing them in their beds at night. ${ }^{11}$ By the nineteenth century, the legend of the walnut tree of Benevento (near Naples) as a gathering place for witches was well known throughout much of the peninsula. Folkloric witches' activities sometimes overlap with those of fairies and the dead: in Italian folklore, noisy night raids and circle-dancing in the cemetery or church square are attributed to all three. There are important distinctions, too, between witches and fairies. Giuseppe Pitrè reported that Sicilian peasants distinguished between the vampiric, maleficent witch (stria, nserra) and the donna di fuori. Sicilian donne di fuori ('women from the outside') or belle signore ('beautiful ladies') documented by Pitrè are creatures somewhere between fairies and witches. ${ }^{12}$ They appear as beautiful women who can enter homes at night through the keyhole. If all is in order, they reward the householders, but they punish dirt and disorder; however, too much attention from the donne di fuori can cause illness, especially in infants. ${ }^{13}$ A similar distinction is made in Sardinia between cogas (lit. 'cooks'), maleficent witches who are said to spiritually cook and eat the bodies of their victims, who slowly decline in health and die; and janas (from Latin Dianas, 'followers of Diana', cf. Neapolitan janare), beautiful women who live in Neolithic shaft tombs, are expert spinners and weavers, and can on occasion intermarry with humans. ${ }^{14}$

Clearly, the folkloric witch is fictional; she represents an embodiment of rural people's worst fears, and her actions do not correspond to any real folk practices documented by ethnographers. Nevertheless, the presence of this character in Italian folklore from all regions indicates the ambivalent feelings villagers had towards those who practised traditional magic and who just might be dangerous streghe.

\section{Il Malocchio, or the evil eye, and its relations}

Much of Italian vernacular magic and healing centres around the evil eye belief complex, a set of interrelated beliefs and practices focused around the idea that an individual can psychically harm another person through the gaze. ${ }^{15}$ Anthropologists have commonly treated the evil eye belief complex as a problem separate from witchcraft; but the two belief complexes are clearly 
interrelated. ${ }^{16}$ The evil eye belief complex encompassed a range of phenomena, from the often inadvertent jettatura or malocchio (evil eye) to more intentional magical attacks, known as attaccatura ('attachment'), fascino or legatura ('binding'), and fattura ('fixing'). ${ }^{17}$ Afflicting someone with the evil eye could happen accidentally, and did not always signify that the guilty party was a witch; but trafficking in the more complex forms of ritual magic necessary to bind or fix involved greater magical knowledge and intent, and was often attributed to witches and folk healers.

The evil eye belief complex is one of the most widespread in the world, spanning the area from the western Mediterranean to North Africa, the Middle East and Central Asia. According to most scholarship the evil eye is the envious eye. ${ }^{18}$ The harsh economic conditions under which most peasants struggled gave rise to a world-view of 'limited good' in which the good in the world (fertility, prosperity, etc.) was thought to exist only in limited quantity. ${ }^{19}$ Therefore, whatever good one had was at the expense of one's neighbour, and vice versa. In the dry Mediterranean climate, good was often associated with moisture and fecundity, while dryness signified barrenness. ${ }^{20}$ This symbolic system extended to the human body: youth was relatively 'wet', while old age was 'dry', and bodily fluids such as semen, milk and blood were symbols of the capacity to reproduce and nurture. Those in a condition of 'wetness', or fecundity, were particularly vulnerable to the envious looks of strangers because they had what others did not; newborn babies, young livestock, new brides, pregnant women and nursing mothers were thought to be especially susceptible. Conversely, those who had cause to feel envy were thought to be able to give the evil eye. In Naples, priests - men who had renounced sexuality and fatherhood - and hunchbacked women, who suffered from a disability that perhaps had made them less than desirable marriage partners, were avoided because they were believed to be intrinsic casters of the evil eye, or jettatori in Neapolitan.

The evil eye can also be given accidentally just by admiring something. When I was in Sardinia, I was cautioned never to express admiration for any living thing without taking pains to remove any evil eye I might have inadvertently placed upon it by touching it and saying 'che Dio lo/la benedica', 'may God bless him/her/it'. The evil eye can also be avoided by ritually spitting (no saliva is ejected, but a 'p' sound is made three times with the lips) after admiring something, symbolically demonstrating one's possession of surplus bodily fluids to avert the drying powers of envy.

There are literally thousands of spells to turn back the evil eye in Italian folklore. Many, appropriately enough, involve water: typically, some matter (wheat seeds, salt, oil, or molten lead) is dropped into a bowl of water and the resulting shapes are interpreted to see whether an 'eye' forms. This diagnosis is often the cure as well, although some cures also involve prayers, such as this one collected by De Martino in Colobraro (Lucania): 


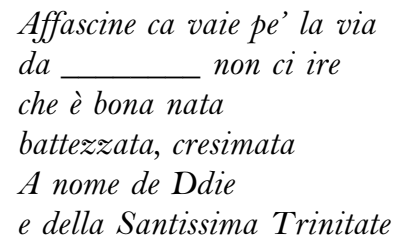

Fascino going along the way

don't go to

for she is well-born

baptized and christened

in the name of God

and the Holy Trinity ${ }^{21}$

Often, mothers and grandmothers knew how to resolve simple cases of the evil eye at home, since children often fell prey to this ailment. More complicated cases required the intervention of a folk healer or specialist. It was far preferable to prevent the evil eye in the first place by using amulets, and Italian folk culture, from ancient times forward, is rife with these devices.

\section{Amulets and protective devices}

Since the evil eye is fundamentally about the lack of fecundity, it should not be surprising that some of the oldest amulets against it are symbols of fertility and regeneration. The most obvious of these is the phallus. The phallus was a common motif in Roman art and sculpture, where its purpose was to bring good luck. This custom has persisted in charms and amulets found throughout Italy in the nineteenth and twentieth centuries. It is most often carved in coral, but can also be made of other materials, and is worn around the neck. Phallic symbols such as fish, roosters, daggers, snakes and keys are also commonly found on protective amulets. Many of these are also euphemisms for the penis in folk speech (e.g. il pesce, 'the fish'; l'uccello, 'the bird'; and chiavare, 'to 'key', to 'screw').

The horn or corno is a closely related symbol. It represents the sexual potency of the mature male herd animal, usually the goat or ram. Horn amulets in bronze and bone, identical in shape to contemporary ones, have been found in numerous Etruscan and Roman-era tombs, attesting to its continuous presence since very ancient times. ${ }^{22}$ Mediterranean coral, because of its blood-red colour, has long been associated with potency and good fortune; horn-shaped amulets were often made of this material, a tradition that continues today. The cheap red plastic horns from souvenir stands that hang from the rear-view mirrors of Italian cars are the modern-day versions of the older coral horns, although they have now become general good luck charms or, in diaspora communities, symbols of ethnic pride. ${ }^{23}$

The mano fica, a fist with the thumb caught between the bent first and 
second fingers, is another common symbol found in amulets against the evil eye. The gesture represents the phallus inside the female genitalia (fica), a graphic opposition to the power of the evil eye. Like the phallus, it can be made of coral, gold, silver, tin, plastic and other materials, and is worn as a charm around the neck, on a bracelet or keychain, or, today, hung on the rear-view mirror of a car. The mano cornuta or horned hand - a fist with the first and little fingers extended - has long been used as a gesture to avert the evil eye, usually with the fingers pointing upwards and the hand waving side to side. ${ }^{24}$

The naturally branching shape of coral lent itself to the creation of multi-pronged amulets. More common in the eighteenth and nineteenth centuries, these are rarely seen today outside of museums. Since according to the logic of magic, more is always better, each branch of the small coral charms was carved with a different protective symbol. Perhaps it is from these multi-pronged coral charms, as well as from an attempt to craft a likeness of the rue flower, that the multi-branched cimaruta evolved. Cimaruta means 'top of the rue (plant)'; these amulets, usually made of silver or tin, had a different symbol on the tip of each branch. These might include phalli, horns, solar disks and crescent moons (symbols of fertility and increase), fish (a symbol of Christ, but also a euphemistic term for the phallus), a key (to protect against epilepsy, but also a phallic symbol), the Sacred Heart of Jesus, and numerous others. Such charms were generally worn under clothing, and were meant to protect from witchcraft.

Rue (ruta graveolens), a medicinal herb native to the Mediterranean with emmenagogue and abortifacent properties, was used by folk healers to treat colic, stomach ailments and skin eruptions. ${ }^{25}$ It was so beneficial that it was believed to protect against witchcraft and the evil eye as well. Rue was often combined with lavender in brevi, small packets or bags made of fabric and worn around the neck next to the skin. Mothers often made these for their children. In addition to beneficial herbs, they might contain garlic, salt, apotropaic stones, prayers, saint's images, sacred objects, and of course amulets such as those described above. ${ }^{26}$ A number of naturally occurring stones and found objects were thought to have apotropaic qualities, and were carried in the pocket as protection or incorporated into other amulets. For example, arrow or spear points from Paleolithic sites, known as pietre della saetta, were believed to be the physical manifestations of lightning, and to be both the cause of and a form of protection against strokes. In some areas of southern Italy, women would find round or kidney-shaped stones of iron-rich clay that rattled from the loose minerals trapped inside. Through sympathetic magic, these became known as pietre della gravidanza, or pregnancy stones, and were believed to protect pregnant women and allow them to carry to term successfully. Pietre del sangue, or bloodstones, were red-spotted jasper thought to stop bleeding if applied to a wound, while pietre stregonie (witch 
stones) or pietre stellari (star stones), polyporic pebbles whose tiny spots were popularly interpreted as 'stars,' were thought to protect against witchcraft. These stones were sometimes carved into cross-shaped amulets and combined with figures of Christian saints, the Virgin Mary or Jesus to enhance their powers. ${ }^{27}$

\section{Folk healing}

Generally, folk healers in Italy fell into one of two categories: ordinary people who knew one or two specific charms, and specialists who possessed a broader magical knowledge involving a variety of techniques and practices. At one time, each village had a number of folk healers who could cure a variety of illnesses. They ranged from those who cured with herbs, magic formulas and prayers to professional sorcerers who were called in serious cases of magical attack. In practice, however, these practitioners differed more in intensity than in kind: sorcerers were often individuals who had learned some cures from a family member, but who broadened their knowledge and became specialized in vernacular magic. Some, like De Martino's 'zio Giuseppe', owned books of magical formulas where, according to one of his informants, 'all knowledge was written'. ${ }^{8}$

The word strega (witch) was never used in reference to these practitioners, except to insult them. They were known as curatori/curatrici (curers), guaritoril guaritrici (healers), or simply as praticos ('knowledgeable ones', akin to the English cunning-folk. Most inherited their craft from a relative, although occasionally a healer claimed to have acquired power directly from a saint. This was the case of an old woman in Castellammare di Stabia (Campania), who in the 1970 s told a folklorist how she obtained her healing powers as a child by falling into a deep trance. Her parents believed her dead, but St Rita 'touched her mouth, bestowing power onto her', and she miraculously recovered. ${ }^{29}$ Another folk healer from central Sardinia told a researcher that one could acquire magic powers by going to a sacred place (a cemetery or church) and receiving su sinzale (a sign), although the nature of the sign was not specified. ${ }^{30}$

Some of these specialized healers employed trance states in their work. Trancing healers might be consulted to discover whether an illness was caused by witchcraft, to find lost or stolen livestock, or for love magic. De Martino movingly describes how one such healer diagnosed and treated supernatural illness:

During the course of her recitation [of the prayer], the healer immerses herself in a controlled dream-like state, and in this condition she merges with the psychic condition of her client, and suffers with him: the altered state causes the healer to yawn, and her suffering with her patient causes her to shed tears. When the healer does not yawn or weep, it means that she was 
not able to discern any spell in effect, and thus her client is not bewitched, but his illness depends on other causes. ${ }^{31}$

In the late 1970s, folklorist Luisa Selis interviewed 'Antonia', a 75-year-old maghiarja (sorceress) from central highland Sardinia. Antonia reported being possessed by three spirits who helped her with her healing work: a priest, who helped her foretell the future; a physician, who helped her cure illnesses; and a bandit, who helped her recover lost livestock. ${ }^{32}$ Trancing healers and diviners like Antonia demonstrate a link with pre-Christian practices that was often recognized by their fellow villagers. About one such healer, an informant of De Martino surmised 'these are people who were born before Jesus Christ ... [they] know ancient science, and maybe remember something that [they] tell us now'. ${ }^{33}$

Most healers, however, were not specialists but ordinary people who possessed some practical or magical knowledge, often in the form of single formulas and prayers, as in the case of Mario from Bessude, whose story I cited at the beginning of this chapter. Formulas are secret and proprietary; they belong to individuals in the community. In the same village, other individuals specialize in curing styes and chalazions, removing the evil eye, or keeping birds and dogs out of fields. These people belong to different families, and thus the remedies, rather than being concentrated in one individual, are diffused throughout the population. As Mario described, healing formulas are passed on from one family member to another at calendrically significant times of year such as Christmas Eve or St John's Eve (June 23). The owner of the formula passes on the power along with the knowledge; once they have been transmitted, the original owner ceases to practise. Often, it is only certain family members who can receive the knowledge, for example a descendent of the opposite sex, or the youngest daughter. It is commonly believed that healers cannot die until they have passed on their knowledge. For the most part, these kinds of healers do not require cash payments; they use their skills as part of a system of balanced reciprocity that knits the community together in an economy of mutual obligation.

The nature of folk cures is quite varied; I can include only a small sample here. Many remedies were mixtures of olive oil and various herbs. De Martino reports that in Lucania, wounds and sores were treated with a mixture of olive oil or animal fat and rue, while Antonia, the Sardinian folk healer, treated boils with an infusion of mallow leaves and olive oil. ${ }^{34}$ For maximum efficacy, herbs were to be gathered on St John's Eve before sunrise.

In Sardinia, many berbos centred on the protection of the herds and crops, the principal livelihood of the community. Eagles would sometimes make off with newborn lambs during the lambing season. Selis collected from Antonia a spell to bind an eagle to a tree in order to prevent it from attacking the 
flock. Antonia would go to the field where the eagle had last been seen, approach the tallest tree, and recite the presura de s'abile (binding of the eagle):
Abile, abile
mares fortes zires
mares zires fortes
pedras d'aeras bortes
pedras de rivu e de mare
in custa robba
non torres a colare.
Eagle, eagle
you circle strong seas
you circle seas strongly
you turn stones of air
river and sea stones
in this flock
do not return to forage. ${ }^{35}$

To keep birds away from crops during the harvest and threshing, the following spell was used in highland Sardinia:
Su cane ardente
non appas in mente
de toccare sa robba mia
in custu monte violente
inie ti balles solu
no appas consolu
de sa robba mia.
The burning dog
does not have it in mind
to touch my crops
in this violent mountain
may you dance alone
without the consolation
of my harvest. ${ }^{36}$

Some folk cures took the form of narratives. Angelina, a 92-year-old native of Arsoli, a town on the border between the regions of Lazio and Abruzzo, gave folklorist Maria Rosaria Tomassi the following cure for jermecara, or worms. The cure would begin on Good Friday. Angelina would make the sign of the cross over the eyes, mouth and ears of her patient, reciting this narrative:

Ecco la settimana santa che arriva

presto arriva e presto si perde

Lunedi santo S. Giobbe ammazza un verme

de martedi santo ne ammaza un'altro 
mercoledi santo corre S. Giobbe

e ne ammazza un'altro

Giobbe con la mano para tutto e ammazza tutto

giovedi santo ne ammazza un'altro

venerdi santo - dopo la giornata inguaribile

di Dio e di S. Giobbe benedetto -

n'ammazza un'altro e finisce tutti

Sabato santo e la resurezzione di Dio

S. Giobbe fa pulizia di tutti

Domenica è la santa Pasqua

che tutti $i$ vermi diventino acqua.

Here comes the holy week

it quickly arrives and quickly leaves

on holy Monday, St Job kills a worm

he kills another on holy Tuesday

on holy Wednesday, St Job runs

and kills another

Job with his hand shields all and kills all

on holy Thursday he kills another

on Good Friday - that terrible day for

God and blessed St Job -

he kills another and finishes them all off

Holy Saturday is the resurrection of God

St Job cleans them all up

Sunday is holy Easter

may all the worms become water. ${ }^{37}$

In this story, St Job is the hero whose battle against the worms follows the story of the Holy Week, the most significant time in the Roman Catholic calendar, and therefore a most propitious time for curing illness. Some folklorists suggest that the patient's suffering is symbolically compared to Christ's passion. ${ }^{38}$ Here we see the adaptation of Christian narrative material to a system based on sympathetic magic, illustrating the almost complete penetration of Catholic ideology in the vernacular magic of Italy.

Taking a patient's measure, a form of magical healing found throughout Western Europe, was adapted by Antonia to cure s'istriadura (lit. 'the stretching'; jaundice). Using string, she would measure the patient's height from head to foot, then the distance between his outstretched arms, from left middle finger to right middle finger. If the height measurement was shorter than the width of the arms, the patient was judged to be affected by s'istriadura. The cure involved cutting the string to pieces and burning it on a tile along with rosemary, incense, wax from a blessed candle and a white barn owl feather. The tile was passed several times over the head of the patient in the sign of the cross; then it was placed on the floor, where the patient had to jump over it three times while inhaling the fumes. ${ }^{39}$ 
Folk healer Maria Paddeu is renowned throughout Sardinia for her ability to cure neonatal hernias. Maria and her brothers are the hereditary keepers of a small shrine to St John the Baptist located just outside the town of Thiesi in north-west Sardinia. Each year on St John's Eve (23 June), women bring their babies to Maria so she can cure them. These small hernias usually resolve themselves as babies grow, but occasionally must be surgically repaired, and many mothers are reluctant to have their babies go under the knife. I was lucky enough to witness a healing during the summer of 1986. With help from her brothers, Maria makes a long vertical cut in the branch of a fig tree that grows outside the shrine. The naked baby is then passed in and out of this opening three times while Maria recites a prayer to St John. ${ }^{40}$ Afterwards, the cleft is wrapped in burlap and sewn with twine. Maria's followers say that when the branch heals over, the child's hernia will disappear. Similar examples of this cure have been collected from several regions in Italy, suggesting that this practice is of fairly ancient derivation. ${ }^{41}$

\section{Magic and counter-magic}

Not all magic was healing magic. The ethnographic record is rich with instances of manipulative or aggressive magic, usually in response to claims of sorcery done against the client. Attaccature, fascini, legature and fatture are examples of this type of magical working, and share an emphasis on the domination of the victim's body through attachment, binding or fixing. The structural features of these spells were often similar, whether they were used for love or to cause illness or death. Love spells often involved the manufacture of philtres or potions using menstrual blood or semen to bind the object of affection through the principle of contagious magic.

A number of spells made use of the transformative power of the moment of the elevation of the host during Mass. A Sicilian spell to make an enemy fall ill entails taking a lemon or an orange to midnight Mass on Christmas Eve, removing a bit of peel, and piercing it with pins while reciting 'Tanti spilli infiggo in quest'arancia, tanti mali ti calino addosso' ('As many pins as I stick in this orange, may as many ills befall you'). The fruit is then thrown into a well or cistern. ${ }^{42}$

Some cases of grave illness are still attributed to magic. As recently as the 1980s, folklorist Luisa Del Giudice documents that her brother-in-law's congenital blood disorder was interpreted by a folk healer in Terracina (Lazio) as the result of sangue legato, 'bound blood' allegedly caused by a spell put on him by a former girlfriend. ${ }^{43}$ This diagnosis points to the fraught nature of social relations in small communities that frequently led to accusations of witchcraft and counter-witchcraft. The folk healer's diagnosis reopened an unresolved social conflict and raised suspicions about a person who in all likelihood was perfectly innocent of any wrongdoing. This case also illustrates 
the pervasive idea that anger and ill will alone are enough to unleash psychic and physical harm. As De Martino demonstrates, folk healers may themselves become caught in this dangerous web: 'people go to [the folk healer] to have fatture undone; but they also believe the old mage can weave evil spells, especially in matters of love, and occasionally he finds himself in the embarrassing situation of having to undo magic he himself made.' ${ }^{44}$

\section{Tarantismo and Argismo}

One of the most fascinating forms of Italian folk healing is the trance-dancing that took place in Puglie and Sardinia in response to the bite (real or imagined) of an insect or spider. These related phenomena have been studied in depth by Italian anthropologists Ernesto De Martino and Clara Gallini, and any treatment I give them here cannot do justice to their complexity. ${ }^{45}$ Briefly put, it was believed that the bite of an insect or spider caused the victim to become possessed by the insect's spirit. In classic tarantulism, described by De Martino, the victim, usually a woman, was typically bitten by a tarantola (not a tarantula, but the European wolf spider, whose bite is painful but not deadly) while performing agricultural labour in the fields during the hot summer months. She might or might not be aware of the bite - in fact the bite itself could be metaphorical; but eventually she developed symptoms ranging from headache to depression and convulsions. Suspecting spider-possession, her relatives would call special musicians to the house to play a range of tunes until the woman's 'spider' recognized the particular rhythms that fit its personality. Then the afflicted woman began to dance. Dancing would continue for hours, sometimes days, until the spider's bite was temporarily exorcised. But the ritual would have to be repeated yearly at the feast of Sts Peter and Paul (29 June) in order for the woman to remain free from symptoms. The lively rhythms of the music accompanying this rite, typically played on tambourines, flute, guitar and accordion, are the origins of the tarantella folk dance. But the ritual, when it was still practised, was anything but merry. Besides the suffering that the illness and cure entailed, being tarantata carried a social stigma. De Martino analyses the practice as an enactment of personal and interpersonal conflicts experienced by peasant women in southern Italy in light of their situation of economic and gender oppression. Many tarantate in fact suffered from emotional frustration connected with love and family difficulties. Edoardo Winspeare's wonderful film 'Bitten' (1998) perfectly captures the atmosphere surrounding the affliction of a young girl when her family forbids her to marry the young man she loves. ${ }^{46}$ In argismo, the Sardinian variant, the biting insect was either a spider (Latrodectus tredecimguttatus) or the mutilla, a brightly-coloured ant-like insect. Both are known in Sardo as argia, 'brightly-coloured', and are identified as the souls of the dead who were not received in the other-world because of their sins. ${ }^{47}$ Arge retained 
characteristics they had while alive: they could be single, married, widowed or priestly, female or (rarely) male; they had names and towns of origin, and a story explaining their return as spider-spirits. The purpose of the ritual was twofold: to identify the possessing spirit and its story, and to placate it by acceding to its demands..$^{48}$ The ritual usually began with a musical exploration to discover, as in tarantism, which music pleased the spirit and would induce it to dance: lullabies for child-argias, love songs for single, engaged or married argias; funeral laments for widowed argias, and so on. This might be followed by a verbal interrogation of the patient by the community in order to discover the identity of the possessing spirit and the story behind its return. This often involved a tale of love, abandonment and betrayal by lovers and family members that would be partially enacted by the possessed individual and the community. In contrast to the Puglie, Sardinian victims were more often male than female; during the course of the ritual cure, the possessed individual might take on the characteristics of the possessing argia, cross-dressing and even undergoing mock childbirth in the case of pregnant argias. The music accompanying the ritual was performed by a specially trained flute or accordion player; the victim's family and community participated in the cure, which involved drinking, partying and dancing over a period of three days. Like her mentor De Martino, Gallini analyses the ritual in terms of its psycho-social role within the small-scale, face-to-face, tension-filled agricultural communities in which it was practised; but she cannot completely escape the survivalism of her theoretical forebears: 'We should at least ask ourselves whether the dance of the argia may have had as its antecedent a pre-Christian possession rite in which the summertime return of the dead was enacted.' ${ }^{49}$

The work of Henningsen on medieval Sicilian beliefs concerning the donne di fuori, as well as the research of Crapanzano on Moroccan healers (1975) and Kligman on Romanian calus (1981) suggest that tarantismo and argismo are variants of ecstatic dance therapies found in many parts of the circumMediterranean. ${ }^{50}$ In many of these vernacular healing systems, illnesses are believed to be caused by spirits, whether embodied in insects (as in argismo and tarantismo) or in supernatural form (iele in Romania, jinn in Morocco, exotica in rural Greece). Certain healers specialize in communicating with these spirits in dreams and trances to discover the cause of the illness, and cures are effected through ritual enactments that may include music and ecstatic dancing.

\section{Disappearance, survival and reclamation: vernacular magic in Italy today}

Already when Gallini was conducting her research project in the 1960s and 1970 , she was dealing with a disappearing custom. By the time I arrived in Sardinia in the mid-1980s, argism had disappeared. 'All of the argias are dead,' 
I was told, perhaps, informants added, because of DDT that was used extensively to kill malaria-causing mosquitoes. But DDT alone was not to blame for the general decline of the traditional folkways within which magical practice had flourished.

The unification of Italy, the establishment of an official Italian language based on the Florentine vernacular, the building of a transportation network, the development of compulsory education based on national norms, and the diffusion of mass media have all contributed to the breakdown of regional isolation and the growth of an Italian national identity. In the last twenty years, globalization and the unification of the European market have brought with them a groundswell of interest in the local, the regional and the indigenous. Yet these changes are the same ones that have led to the rupture of traditional rural folkways that were the cradle of Italian vernacular magic.

The social changes of the late twentieth century have profoundly transformed the peasant villages of Italy and have integrated them into a global economy. In much of Italy, post-war urbanization and immigration stripped the villages of half their population. Legal reforms abolished the old, exploitative landholding systems that strangled contadini; contemporary agriculturalists practise their trade only part-time, working in factories or in the expanding service economy as well. Women now fill positions in the labour market and in politics that the emigrating men left empty, and mass tourism, cable TV and the Internet have introduced new models of identity and consumption. The old sense of the precariousness of human life has lightened somewhat as a result of better conditions and new opportunities, bringing a decline in evil eye belief and witchcraft accusations. While some customs remain - many young mothers still put their babies' undershirts on inside-out - the explanations have changed: instead of saying this is to keep away the evil eye, my informants now tell me the purpose of this custom is to protect babies' delicate skin from the chafing of the seams. Italians who consult magical healers today are much less likely to do so because they believe themselves to be victims of the evil eye or a fattura; they are more likely to want information about their futures, a love affair or a job situation. ${ }^{51}$

But magic and occultism are not dead in Italy; they are finding new expressions in a plethora of New Age religions and practices, mostly concentrated in urban areas that build upon Italy's magical heritage. In her 1990 survey, Cecilia Gatto Trocchi found a range of magical and occult practices in Italy, from traditional healers now located in urban areas to esoteric groups such as the Rosicrucian Brotherhood and the Theosophical Society, to New Age practices such as fire-walking and crystal healing. ${ }^{52}$ More recently, the Puglie is seeing a renewed interest in tarantismo. The new tarantati, however, bare little resemblance to the women studied by De Martino; they are male and female, under forty, and belong mostly to the middle classes. Calling themselves 'tarantolati, these young people gather at night to play frame 
drums and dance ecstatically, striving to achieve alternate states of consciousness in a kind of rave to the rhythms of traditional folk music. Paolo Apolito analyses their practice as a post-modern critique of rationalism, as well as an expression of a uniquely local identity in a globalizing world..$^{53}$

Because of its relatively late development as a modern industrial nationstate, Italy is perhaps in a unique position in Europe, in that traditional vernacular magic coexists with newer reclaimed forms such as those documented by Apolito. ${ }^{54}$ In the case of folklore reclamation, it is not only the forms of folklore previously repudiated as backwards and irrational that are being reclaimed; it is the very interpretive structures erected by nineteenthand early twentieth-century folklorists and ethnologists that are being called into question. The Sardinian folk-rock group Tazenda included in its 1992 album Limba ('Tongue', 'Language') a song entitled 'Preghiera Semplice' ('Simple Prayer') that alludes, in part, to the difficulty of reclaiming alternate spiritualities after a cultural hiatus:

Dansat sa majalza, sa majalza dansat

archimissas in sas manos

Ballu, ballu tundu

abbaticamus su mundu

brincamos che indianos

Sa vida, sa sorte, su muscu 'e sa terra mia

Sa muida 'e sa morte, sas dudas mias.

The sorceress dances, the sorceress dances

Wheat sprigs in her hands

Dance, dance the circle dance

We tread the earth

We jump like Indians

Life, fate, the smell of my land

The rattle of death, my doubts.

In this song, the sorceress dances holding wheat sprigs, symbols of the harvest and life's potential for renewal. The circle dance, still performed at all the summer harvest festivals in the island's small towns, is often the only time the community gathers together, forming a chain that winds in and out, spiralling inward, then unwinding, bringing each member of the dance face to face with every other dancer. But in this context, the dancers trample the earth, the source of the wheat sprigs; they jump like Indians, an allusion to the survivalism of the early ethnologists, who compared peasant practices to those of Third World peoples. In the end, the doubts about the very sacredness of the dance, the power of the sorceress brought on by the rationalist paradigm are compared to a death rattle. It is unclear whether this is more powerful than, or equally balanced with, the life, fate and the smell of the land - the local, the indigenous, the quick, the stuff of life itself. 


\section{Notes}

1 Leonard Norman Primiano, 'Vernacular Religion and the Search for Method in Religious Folklife', Western Folklore 54, 1 (1995) 39, 45.

2 Primiano, 'Vernacular Religion', p. 38.

3 Primiano, 'Vernacular Religion', p. 41.

4. As Owen Davies has shown in his study of cunning-men in provincial England, many cunning-folk possessed magical texts and formularies whose material could turn up in a number of social contexts, both learned and popular: Owen Davies, Cunning-Folk: Popular Magic in English History (London, 2003).

5 Giuseppe Bellucci, Il feticismo primitivo in Italia e le sue forme di adattamento (Perugia, [1919] 1983).

6 Cecilia Gatto Trocchi, Magia ed esoterismo in Italia (Milan, 1990).

7 Paolo Apolito, 'Tarantismo, identità locale, postmodernità', in Apolito et al., Transe, guarigione, mito: antropologia e la storia del tarantismo (Nardo, 2000), pp. 137-43; Luisa Del Giudice, 'Mountains of Cheese, Rivers of Wine: Paesi di Cuccagna and Other Gastronomic Utopias', in Del Giudice and Gerald Porter (eds), Imagined States: Nationalism, Utopia and Longing in Oral Cultures (Logan, 2001), pp. 11-63.

8 Owen Davies, Witchcraft, Magic and Culture, 1736-1951 (Manchester, 1999); Jeanne Favret-Saada, Deadly Words: Witchcraft in the Bocage (Cambridge, 1980).

9 Davies, Witchcraft, Magic and Culture; Owen Davies, A People Bewitched: Witchcraft and Magic in Nineteenth-Century Somerset (Bruton, 1999).

10 See Alfredo Cattabiani, Lunario: dodici mesi di miti, feste, leggende e tradizioni popolari d'Italia (Milan, 1994), pp. 207-8.

11 Ernesto De Martino, Sud e magia (Milan, [1966] 1987), p. 71. On such nocturnal experiences see David Hufford, The Terror that Comes in the Night: An Experience-Centered Approach to Supernatural Assault Traditions (Philadelphia, 1982).

12 Gustav Henningsen, in his careful review of Spanish Inquisition documents from Sicily, reveals that during the sixteenth century, the term donne di fuori referred to both fairies and people of both genders who were believed to ride out with them at night. These individuals were usually folk healers who could cure illnesses caused by the fairies, often as a result of some unwitting offence against them. The usual cure involved a ritual supper offered to the fairies by the victim. The fairies, accompanied by the healers in spirit form, would come to the victim's home on an appointed night where they would dance, celebrate and spiritually consume the food, thus curing the afflicted person: Gustav Henningsen, “The Ladies from Outside”: An Archaic Pattern of the Witches' Sabbath', in Gustav Henningsen and Bengt Ankarloo (eds), European Witchcraft: Centers and Peripheries (Oxford, 1993), pp. 191-215. These medieval Sicilian beliefs have interesting parallels throughout the modern Mediterranean. In rural Greece, as recently as the 1960s, certain folk healers specialized in curing ills brought about by the fairies, known as exotica ('those from outside'). Anthropologist Vincent Crapanzano, working in Morocco in the 1960s, documented a belief system centred on the jinn (fairies) and their human followers, folk healers belonging to religious brotherhoods who could cure illness by performing a trancedance to special music. The queen of the jinn, known as 'A'isha Qandisha, could appear either as a beautiful woman or a hideous hag, but always had a non-human feature, such as camel toes. Healers consulted 'A'isha Qandisha in their dreams, where she explained the cause of the illness and its cure: Vincent Crapanzano, 'Saints, Jnun, and Dreams: An Essay in Moroccan Ethnopsychology', Psychiatry 38 (1975) 145-59. In the 1970s, folklorist Gail Kligman documented Romanian brotherhoods of trance dancers who specialized in curing ailments thought to be caused by iele (fairies), 
whose patron saint was Diana or Irodeasa: Gail Kligman, Calus: Symbolic Transformation in Romanian Ritual (Chicago, [1977] 1981).

13 Giuseppe Pitrè, Usi, costumi, credenze e pregiudizi del popolo siciliano (Palermo, 1889), pp. iv, 153.

14. Antonangelo Liori, Demoni, miti e riti magici della Sardegna (Rome, 1992), pp. 107-11.

15 De Martino, Sud e magia, p. 15.

16 Willem de Blécourt, 'The Witch, her Victim, the Unwitcher and the Researcher: The Continued Existence of Traditional Witchcraft', in Willem de Blécourt, Ronald Hutton and Jean La Fontaine, Witchcraft and Magic in Europe: The Twentieth Century (Philadelphia, 1999), p. 147.

17 De Martino, Sud e magia, p. 15.

18 See De Martino, Sud e magia; Alan Dundes, 'Wet and Dry, the Evil Eye', in idem (ed.), The Evil Eye: A Casebook (Madison, 1992), pp. 257-312.

19 George M. Foster, 'Peasant Society and the Image of Limited Good', American Anthropologist 67 (1965) 293-315.

20 In Roman slang, the expression 'non mi seccare [le palle]', literally 'don't dry up my testicles', or 'don't annoy me', is a current reflection of this underlying system of binary oppositions. Similarly, the Roman slang expression 'rimanerci secco/a', 'to dry up of it', is a euphemism for dying.

21 De Martino, Sud e magia, p. 17.

22 Bellucci, Il feticismo primitivo, p. 50.

23 Frances M. Malpezzi and William M. Clements, Italian American Folklore (Little Rock, 1992), p. 121.

24. This symbol needs to be deployed with care as it has other meanings, however. Jabbed towards another with the fingers pointing at them, this gesture is a powerful insult meaning 'cuckold.'

25 Malcolm Stuart (ed.), The Encyclopedia of Herbs and Herbalism (New York, 1979), pp. $256-7$.

26 Alfonso Di Nola, Lo specchio e l’olio: le superstizioni italiane (Bari, 1993), pp. 14-15.

27 Bellucci, Il feticismo primitivo, pp. 80-5, 92, 87, 100.

28 De Martino, Sud e magia, pp. 70-2.

29 Di Nola, Lo specchio e l'olio, p. 40; my translation.

30 Luisa Selis, 'Prime ricerche sulla presenza delle streghe in Sardegna oggi', in Maria Bergamaschi et al., L'erba delle donne: maghe, streghe, guaritrici (Rome, 1978), p. 139.

31 De Martino, Sud e magia, p. 17; my translation.

32 Selis, 'Prime ricerche sulla presenza delle streghe', p. 141.

33 De Martino, Sud e magia, pp. 70-1.

34. De Martino, Sud e magia, pp. 38-9; Selis, 'Prime ricerche sulla presenza delle streghe', p. 143.

35 Selis, 'Prime ricerche sulla presenza delle streghe', p. 141

36 Liori, Demoni, miti e riti magici, p. 189.

37 Maria Rosaria Tomassi, 'La Furnicella', in Bergamaschi et al., L'erba delle donne, p. 150.

38 Tomassi, 'La Furnicella', p. 150.

39 Selis, 'Prime ricerche sulla presenza delle streghe', p. 142.

40 I was unable to collect the words, as this is secret material that Maria can pass on only to another family member.

41 Di Nola, Lo specchio e l'olio, p. 116.

42 Di Nola, Lo specchio e l'olio, p. 49. Di Nola gives this incantation in Italian and not in Sicilian. See also the 'Conjuration of Lemons and Pins', in Charles G. Leland, Aradia, or the Gospel of the Witches (Custer, [1890] 1990), pp. 29-32.

43 Luisa Del Giudice, personal communication, 1999. 
44. De Martino, Sud e magia, p. 71; my translation.

45 Ernesto De Martino, La terra del rimorso (Milan, 1961); Clara Gallini, La ballerina variopinta (Naples, 1988).

46 Recent historical research by Maria Rosaria Tamblé has revealed a possible connection between tarantismo and witchcraft. In the trial of Caterina Palazzo of Calabria in 1627, the folk healer is accused of having exorcised a number of clients who suffered from tarantulism. Although she denied the accusations, a story emerged during the trial linking the venomous spider with other animal familiars, such as toads and frogs, known to aid witches in their diabolical workings: Tamblé, 'Tarantismo e stregoneria: un legame possibile', in Transe, guarigione, mito, pp. 101-18.

47 Gallini, La ballerina variopinta, p. 25.

48 Gallini, La ballerina variopinta, p. 42.

49 Gallini, La ballerina variopinta, p. 96; my translation.

50 Henningsen, “'The Ladies from Outside”'; Crapanzano, 'Saints, Jnun, and Dreams'; Kligman, Calus: Symbolic Transformation.

51 Cecilia Gatto Trocchi, Magia ed esoterismo in Italia (Milan, 1990), p. 89.

52 Gatto Trocchi, Magia ed esoterismo.

53 Apolito, 'Tarantismo, identità locale, postmodernità', pp. 137-43.

54 For a discussion of folklore reclamation, see Sabina Magliocco, 'Coordinates of Power and Performance: Festivals as Sites of (Re)Presentation and Reclamation in Sardinia', Ethnologies 23,1 (2001) 167-88. 